\title{
Medida de la eficacia de dos hidrofugantes aplicados a rocas graníticas
}

\section{Determination of the efficacy of two water repellents applied to granite}

Fecha de recepción: 10-VII-97

Fecha de aceptación: 25-IX-97
T. RIVAS, B. SILVA y B. PRIETO

Dpto. de Edafología. Univ. de Santiago de Compostela

\section{RESUMEN}

Se presentan los resultados de la aplicación de dos tratamientos hidrofugantes a tres rocas graniticas ampliamente utilizadas en la construcción y restauración en Galicia. Se ha determinado la profundidad de penetración de los hidrofugantes a través de la absorción capilar, la eficacia de los tratamientos comparando dos parámetros relacionados con el mojado superficial (ángulo de contacto roca-agua y tiempo de absorción de microgotas), y las variaciones en el color y en la permeabilidad al vapor. Se comprueba que si bien ambos tratamientos penetran de forma muy escasa en las rocas graniticas y reducen significativamente la permeabilidad al vapor, mejoran sensiblemente su comportamiento frente al mojado superficial sin modificar el color original. El ángulo de contacto, el tiempo de absorción de microgotas y la determinación colorimétrica utilizada, constituyen una buena metodología en la evaluación de los efectos de tratamientos hidrofugantes en rocas graniticas; sin embargo, el fuerte carácter heterogéneo este tipo de rocas, la mineralogia y el tipo de fisuración predominante, suponen un factor de variación significativo en la determinación de estos parámetros.

\begin{abstract}
SUMMARY
We evaluated the efficacy of two water-repellents applied to three types of granitic rock widely used in building construction and restoration in Galicia (NW Spain). The depth of penetration of the water-repellents was determined by measuring capillary absorption by the treated rock. The efficacies of the water-repellent were evaluated in terms of two parameters characteristic of surface wetti: water-rock contact angle and the time taken for absorption of microgroplets. The effects of the treatments on the rocks' surface colour and permeability to water vapour were also determined. The results indicate that neither water-repellent effectively penetrates the rock surface, and both induce indesirably high reductions in vapour permeability. Notwithstanding, both agents effectively improved the rocks' resistance to surface wetting, without altering its surface colour. Overall, determination of water-rock contact angle and the time taken for absorption of microdroplets, together with colorimetric characterization of the treated rock, constitues an useful approach to evaluation of the effects of water -repellents on granitic rocks. Nonetheless, it should be borne in mind that the marked heterogeneity of this type of rock, and the associated mineralogy and dominant type of fissuration are sources of considerable variation in the measurement parameters.
\end{abstract}

\section{INTRODUCCIÓN}

Los aspectos relacionados con la problemática de la conservación de las rocas graníticas usadas en la construcción son poco conocidos y son escasos los

\section{INTRODUCTION}

The conservation of granitic buildings and monuments is an important problem that has hitherto received little attention. One reason for this is that Italy and the 
trabajos de investigación específicos para este tipo de rocas ya que en los países pioneros en estudios de conservación y restauración, como son Italia y otros países de Centro Europa, las rocas usadas en el Patrimonio Monumental construido son otras. Por otra parte, las particularidades de las rocas graníticas, como su carácter polimineral y su porosidad de tipo fisural, hacen imposible extrapolar a ellas los resultados obtenidos para otros tipos rocosos.

El incremento en el número de intervenciones de restauración en el Patrimonio Monumental Gallego, casi exclusivamente construido con rocas graníticas, reclama el apoyo de la investigación aplicada en laboratorio. Por esta razón se ha planteado un estudio sobre la eficacia de dos tratamientos de hidrofugación aplicados a tres granitos ampliamente utilizados en la construcción de edificios en Galicia.

Los productos hidrofugantes ensayados son dos polisiloxanos. Se ha determinado el consumo, la profundidad de penetración mediante las cinéticas capilares, y la eficacia, comparando, antes y después de los tratamientos, el tiempo de absorción de microgotas y el ángulo de contacto roca-agua. Se ha determinado también la variación del color tras el tratamiento así como las modificaciones en la permeabilidad al vapor de agua, propiedad de los materiales rocosos que no debe verse modificada por un tratamiento superficial. Dado que los parámetros utilizados en este trabajo para valorar la eficacia y las modificaciones introducidas por los tratamientos en los materiales rocosos son usados habitualmente en otros tipos rocosos de naturaleza no ígnea, los resultados obtenidos se han analizado con el propósito de determinar si son válidos para caracterizar el efecto de los tratamientos en rocas graníticas, de marcado carácter heterogéneo.

\section{MATERIAL Y MÉTODOS}

\section{Caracterización de los granitos}

Se seleccionaron tres granitos diferentes, denominados Roan (R), Baleante (B) y Axeitos (AX). El granito denominado Roan procede de los montes situados al Oeste de Santiago y fue ampliamente utilizado en la construcción del centro histórico de la ciudad. El granito Baleante, que procede de la península del Barbanza, es una roca que actualmente está siendo muy utilizada en la restauración de monumentos antiguos y en la construcción de edificios nuevos en Santiago, ya que posee color y textura semejantes al primer granito. El tercer granito seleccionado, denominado Axeitos, procede del lugar del mismo nombre en el municipio de Riveira (A Coruña) y constituye el material de construcción del Dolmen de Axeitos y de la arquitectura popular de la zona. other Central European nations that have pioneered research into the conservation of stonework have architectural heritage built mainly from limestone and marble. Unfortunately, the experience gleaned from these studies is rarely applicable to granite owing to its peculiar nature, in particular its polymineralogy and fissural porosity.

Galicia, in NW Spain, has a rich architectural heritage of mainly granitic buildings and monuments. To support conservation and restoration of these edifices, we are carrying out laboratory studies to determine the efficacy and durability of conservation treatments for granitic stone. In this work we present the results of a study of the efficacy of two polysiloxane water repellents applied to three types of granitic rock widely used in construction in Galicia.

The efficacies of the water repellents were evaluated by comparing rock-water contact angles and times taken for absorption of microdroplets, before and after application of the water repellent. Also determined were uptake, depth of penetration, by measuring the kinetics of capillary absorption by the treated rock, and the effects of each treatment on the rocks' surface colour and permeability to water vapour, which should not be modified by a surface treatment. Although these parameters have been widely used to evaluate the efficacy and effects of surface treatments applied to non-igneous rocks, they have been little used to characterize the effects of such treatments on heterogeneous igneous rocks such as granite. One of the aims of this work was thus to confirm the validity of using this approach to study surface treatments applied to granitic rocks.

\section{MATERIALS AND METHODS}

\section{Characterization of the granites}

The granites studied were Roan granite, which is quarried to the west of Santiago de Compostela and was extensively used in the construction of this city; Baleante granite, which is quarried from the Barbanza Peninsula (A Coruña) and is used for construction and restoration work in Santiago because of its similar colour and texture to Roan granite; and Axeitos granite, which is quarried near Axeitos Riveira, $A$ Coruña) and was used in the construction of the Axeitos Dolmen and of traditional structures in its vicinity. Samples of sound Roan, Baleante and Axeitos granite (RS, BS and AX, respectively) were taken from the source quarries, together with samples of the Roan and Baleante granites that showed signs of incipient weathering (RW and $B W$, respectively). 
Se realizó un muestreo de los granitos seleccionados en las canteras de origen, tomando muestras sanas de los tres (Roan sano-RS-; Baleante sano -BS-; Axeitos-AX) y muestras que aparentaban un estado inicial de alteración (Roan alterado -RA-; y Baleante alteradoBA-). Estas muestras se caracterizaron desde el punto de vista mineralógico por difracción de rayos $\mathrm{X}$ y desde el punto de vista petrográfico mediante el estudio de láminas delgadas por microscopía petrográfica. En la elaboración de las láminas delgadas, se adicionó un colorante fluorescente (Rodamina B) para la visualización de los huecos y fisuras mediante microscopía óptica de fluorescencia.

Con diez probetas de dimensiones $5 \times 5 \times 5 \mathrm{~cm}$ de cada granito se determinó la porosidad accesible al agua (PA), el contenido de agua en saturación (WS) y las densidades real (DR) y aparente (DA) según (1) y sobre tres probetas de dimensiones $5 \times 5 \times 0,5 \mathrm{~cm}$ de cada granito se determinó el coeficiente de permeabilidad al vapor según ( 2 y 3 ). Las probetas se cortaron considerando como superficie de referencia el plano horizontal de cantera (o plano de levante); el coeficiente de permeabilidad al vapor de agua se determinó estableciendo el flujo de vapor de agua perpendicularmente a dicho plano.

\section{Aplicación de los hidrofugantes}

Los productos hidrofugantes ensayados, Siliker $S-101$ (Wacker Química Portuguesa) y Tegosivin Ht-100 (Goldschmidt), son siloxanos oligoméricos de cadena corta que reaccionan con el agua de la piedra y se transforman en polisiloxanos. Siliker $S-101$ se aplica directamente mientras que Tegosivin $\mathrm{Ht}-100$ se aplica diluido en White Spirit al $10 \%$ en peso, añadiendo a la dilución un catalizador en un $2 \%$ en peso de hidrofugante.

La aplicación se realizó en una sola cara de veinte probetas de dimensiones $5 \times 5 \times 5 \mathrm{~cm}$ de cada granito, sumergiéndolas hasta una profundidad de $1 \mathrm{~cm}$ durante 30 segundos, diez en Tegosivin y las otras diez en Siliker. Las probetas destinadas a medir la permeabilidad al vapor de agua se hidrofugaron por inmersión total durante 30 segundos. La determinación de la cantidad de producto absorbido y el consumo se determina por la diferencia de peso de la probeta antes y después de la aplicación, y la cantidad de materia seca polimerizada se determina por la diferencia de peso tras 30 dias de la aplicación.

\section{Profundidad de penetración}

Para medir la profundicad de penetración de los hidrofugantes, se han aplicado dos métodos. Por una
The samples were characterized mineralogically by $X$ ray diffractometry, and by petrographic and fluorescence microscopy of thin sections, in the latter case impregnating the section with resin containing the fluorescent dye "Rhodamine $B^{\prime \prime}$ to aid visualization of hollows and fissuration in the rock.

Test samples of each granitic rock were cut from the raw rock, taking the horizontal plane of the quarry as reference plane, and their mass was recorded. For each granite, ten $5 \times 5 \times 5 \mathrm{~cm}$ test samples were used to determine open porosity (OP), water saturation (WS), real density $(R D)$ and bulk density $(B D)$, using published methods (1); and three $5 \times 5 \times 0.5 \mathrm{~cm}$ test samples were used to determine the coefficient of vapour permeability (VP) in the direction perpendicular to the horizontal plane of the quarry (see refs. 2 and 3).

\section{Application of the water repellents}

The water repellents tested are short-chain siloxane oligomers that form polysiloxanes upon reaction with water in the stonework treated. "Siliker S-101" (Wacker) is applied directly to the stone, whereas "Tegosivin Ht-100" (Goldschmidt) must firstly be diluted to a $10 \%(w / w)$ solution in white spirit and mixed with $2 \%(w / w$ of water repellent $)$ of a polymerization catalyst.

Only one face of the test samples $(5$ or $10 \times 5 \times 5 \mathrm{~cm}$ cubes or rectangular blocks) was treated, this face always being parallel to the plane of the quarry floor. The test sample was weighed and then immersed in the preparation to a depth of $1 \mathrm{~cm}$ for $30 \mathrm{~s}$ (the $0.5 \mathrm{~cm}$ thick samples used for determination of the coefficient of vapour permeability were fully immersed in the preparation, also for 30s). After drip-drying over the solution for 10s, the test sample was inverted and reweighed, the mass gained being recorded as the amount of water repellent absorbed. The sample was also reweighed 30 days after treatment, this mass difference (mass 30 days after treatment-mass of untreated block) being recorded as the amount of dry polymer retained by the rock.

\section{Depth of penetration}

The depth of penetration of the water repellents into the granites was estimated by two methods. The first 
parte, se ha observado la diferencia de color producida por el mojado con agua de cortes perpendiculares a la superficie tratada.

Por otra parte, se han comparado las cinéticas capilares de las probetas antes y después de ser tratadas.Si se establece el ascenso capilar perpendicularmente a la cara tratada (colocada hacia arriba), el frente capilar asciende hacia el área tratada y cuando la alcanza, la repelencia de esta zona crea una barrera frente al agua que impide que ascienda más, definiendo una cara superior virtual.

Si la situación de la cara superior de las probetas durante el ensayo de absorción capilar se predice de forma teórica como el punto de inflexión entre el primer y segundo tramo de la cinética, lo mismo se puede hacer con respecto a la situación de la capa hidrofugada. De esta forma, la diferencia en el contenido de agua en este punto de inflexión entre las probetas no tratadas y las tratadas determina la posición del área hidrofugada y, por tanto, la profundidad de penetración (4). Si se asume que al final del test, el agua está uniformemente distribuida en la probeta, la profundidad de penetración se estima a través de la fórmula: involved cutting two blocks in half perpendicular to the treated surface and then soaking each half with water.

The depth of penetration of the water repellent was taken as the mean depth at which its presence was made evident by a change in colour of the wet granite. $A$ more accurate estimate of the depth of penetration was obtained as follows (4).

The kinetics of capillary absorption of ten test samples were determined before and after treatment, by standing each test sample in $2 \mathrm{~mm}$ of water with its treated face uppermost and weighing it at intervals over a period of eight days. The kinetic data were plotted and the point of inflexion between the first and second absorption phases was taken to indicate that the water had reached the top of the test sample, or the bottom of the water-repellent layer. Assuming the absorbed water to be uniformly distributed in the sample, the depth of penetration, $p$, can be estimated using the formula: siendo $\mathrm{p}$, la profundidad de impregnación (cm); $\left(Q_{t}-Q_{n t}\right)$ la diferencia de agua absorbida en el punto de inflexión por la probeta tratada y la no tratada ( $g r) ; P_{n t}$, el peso seco de la probeta no tratada (gr); $Q_{n t}$, la cantidad de agua absorbida por la probeta no tratada en el punto de inflexión (gr); $\delta_{\mathrm{ap}}$, la densidad aparente de la roca (gr/ $\mathrm{cm}^{3}$ ) y A, la sección de la probeta $\left(\mathrm{cm}^{2}\right)$.

\section{Caracterización colorimétrica}

Para la caracterización del color, se utilizó un colorímetro para sólidos, expresando los datos en las coordenadas L*, (que define la luminosidad del color) y las coordenadas $a^{*}$ y b* (que definen, respectivamente, la escala cromática del rojo al verde y del azul al amarillo) (CIE, Color Space). Esta determinación se realizó en 6 probetas de cada granito (tres tratadas con Tegosivin y las otras tres tratadas con Siliker), de dimensiones $10 \times 5 \times 5 \mathrm{~cm}$, realizando 18-20 mediciones por probeta en la cara $10 \times 5 \mathrm{~cm}$

\section{Coeficiente de permeabilidad al vapor}

El coeficiente de permeabilidad al vapor se determinó perpendicularmente a la cara tratada en tres probetas de dimensiones $5 \times 5 \times 0,5 \mathrm{~cm}$ de cada granito (tratado y sin tratar), según ( 2 y 3$)$. where $Q_{t}$ and $Q_{m}$ are the masses (in $\mathrm{g}$ ) of water absorbed by the treated and untreated test samples at the times corresponding to their respective points of inflexion; $P$ is the mass (in $g$ ) of the dry, untreated test sample; and $\delta_{\text {ap }}$ and $A$ are its bulk density (in $\mathrm{g} / \mathrm{cm}^{3}$ ) and cross-sectional area (in $\mathrm{cm}^{2}$ ), respectively.

\section{Colorimetric characterization}

A colorimeter for solids was used to determine the colour at $18-20$ points on the $10 \times 5 \mathrm{~cm}$ face of three $10 \times 5 \times 5 \mathrm{~cm}$ test samples of each untreated and treated granite. The results are expressed as the rectangular coordinates $L^{*}$ (which defines the luminosity of the colour), $a^{*}$ and $b^{*}$ (which define the chromatic scales from red to green and from blue to yellow respectively).

\section{Coefficient of vapour permeability}

The coefficient of vapour permeability (VP) was determined perpendicular to the treated face of three $5 \times 5 \times 0.5 \mathrm{~cm}$ test samples of each untreated and treated granite, as per refs. 2 and 3. 


\section{Determinación de la eficacia de los hidrofugantes}

Para medir la eficacia de los hidrofugantes, se determinó el ángulo de contacto roca-agua y el tiempo de absorción de microgotas, según (3) en veinte probetas de cada granito sin tratar. Posteriormente, se trataron 10 probetas con un hidrofugante y $10 \mathrm{con}$ el otro, volviéndose a determinar sobre ellas el ángulo de contacto y el tiempo de absorción de microgotas.

Tiempo de absorción de microgotas (3)

Se deja caer una gota de 10 microlitros de agua destilada desde una distancia de $10 \mathrm{~mm}$ sobre la superficie de probetas de $5 \times 5 \times 5 \mathrm{~cm}$ y se mide el tiempo necesario para su absorción total. Este proceso se repite para una superficie de referencia de capacidad de absorción nula (un vidrio), pero en este caso se mide el tiempo necesario para la completa evaporación de la microgota. El tiempo de absorción de microgotas $\left(t_{p}\right)$ se expresa en porcentaje de tiempo medio de evaporación de las microgotas sobre el vidrio, según la expresión:

\section{Determination of the efficacy of the water repellents}

The following measurements were made on twenty untreated test samples, and then on half of these samples treated with one or other of the water repellents.

\section{Microdroplet absorption time (3)}

A $10 \mu \mathrm{L}$ microdroplet of distilled water was allowed to fall from a height of $10 \mathrm{~mm}$ onto the face of $5 \times 5 \times 5 \mathrm{~cm}$ test samples, and the time taken for the rock to fully absorb the droplet (t) was recorded. The same test was performed using a reference surface with zero absorption capacity (a glass), but in this case the time taken for complete evaporation of the droplet was recorded.The relative microdroplet absorption time $\left(t_{p} \%\right)$ was calculated as a proportion of the mean evaporation time from three sites on the glass reference surface, using the expression:

$$
\mathrm{t}_{\mathrm{p}}=100 \times \Sigma\left(\mathrm{t}_{\mathrm{i}} / \mathrm{t}_{\mathrm{v}}\right) / \mathrm{n}
$$

Para cada superficie se utilizaron 10 microgotas, $n$.

\section{Ángulo de contacto.}

Se deja caer una gota de 4 microlitros de agua destilada desde una altura de $10 \mathrm{~mm}$ sobre la superficie de probetas de $5 \times 5 \times 5 \mathrm{~cm}$ y se mide después de 10 segundos la base (a) y la altura (h) de dicha gota mediante un micrómetro acoplado a una lupa binocular con una ampliación de 10 aumentos. Para cada superficie medida (de $25 \mathrm{~cm}^{2}$ ) se utilizaron 10 microgotas. El ángulo de contacto se determina a partir de la expresión:

$$
\alpha=2 \operatorname{arctg}(2 \mathrm{~h} / \mathrm{a})
$$

\section{Análisis estadístico}

Los resultados de la permeabilidad al vapor de agua, medidas colorimétricas, ángulo de contacto roca-agua y tiempo de absorción de microgotas se han sometido a un análisis de varianza de dos vías, Modelo III, siendo el factor fijo el tratamiento aplicado (ninguno, Tegosivin, Siliker) y el factor aleatorio la probeta, es decir, la variabilidad propia de la muestra de roca. Esto se hizo con el propósito de comprobar hasta qué punto las variaciones observadas en los parámetros después de los tratamientos se deben al efecto de éstos o a la propia heterogeneidad de las rocas graníticas.

\section{RESULTADOS}

\section{Caracterización de los granitos}

El granito de Roan es un granito de grano fino, de where $n$ is 10 (the number of microdroplets used).

\section{Rock-water contact angle}

A $4 \mu \mathrm{L}$ microdroplet of distilled water was allowed to fall from a height of $10 \mathrm{~mm}$ onto the face of $5 \times 5 \times 5 \mathrm{~cm}$ test samples. After $10 \mathrm{~s}$, the area of the base (a) and height (h) of the drop were measured using a micrometer and a binocular magnifying glass (10X magnification). Microdroplets were allowed to fall at ten different sites on the $25 \mathrm{~cm}^{2}$ treated face. In each case, the contact angle was calculated using the expression:

\section{Statistical analysis}

Statistically significant differences among the colour co-ordinates, coefficients of permeability, microdroplet absorption times, and rock water contact angles obtained for the untreated and treated test samples were identified by comparing the results using a nested two-way analysis of variance (ANOVA, Model III) with fixed effect factor "water repellent treatment" (none, "Tegosivin" or "Siliker") and random effect factor "test sample".

\section{RESULTS}

\section{Characterization of the granites}

"Roan" granite is a fine grained granite that has a 
textura equigranular panalotriomorfa. Aparentemente es bastante homogéneo, no apreciándose orientación.

Sus componentes principales son cuarzo, plagioclasa, feldespato potásico, moscovita y biotita. Como accesorios posee apatito y circón. Baleante es un leucogranito rico en moscovita, de granulometría medio-gruesa y con una marcada orientación mineral. Sus componentes son cuarzo, plagioclasa, feldespato potásico, moscovita y biotita, y como accesorios, apatito. Axeitos es un granito posthercínico de coloración rojiza, de tamaño de grano medio-grueso y con una débil orientación mineral. Sus componentes son cuarzo, ortosa, plagioclasa, biotita y moscovita, y circón y opacos como accesorios.

La observación de las muestras de los granitos al microscopio óptico de fluorescencia permite visualizar el grado y tipo de fisuración. Roan sano (RS) presenta fisuración, fundamentalmente de tipo intragranular en la plagioclasa e intergranular en el cuarzo, mientras que Baleante sano (BS) posee una fisuración de tipo intragranular en la plagioclasa y biotita e inter y transgranular en el feldespato y cuarzo. Las muestras alteradas RA y BA muestran una mayor densidad de fisuración que sus correspondientes muestras sanas. Axeitos (AX) es de los tres granitos el que posee la mayor densidad de fisuras de tipo transgranular, afectando a los cristales de cuarzo y feldespato potásico y en menor medida, fisuración intergranular.

Por difracción de rayos X (Tabla 1) se detectan, además de los minerales esenciales de las rocas graníticas, trazas de caolinita en todas las muestras, tanto en las alteradas como en las que se habían considerado sanas. En las muestras RS, RA y AX se detectan también trazas de vermiculita.

En la tabla 2 se presentan los valores de porosidad accesible al agua, densidad aparente y real y contenido de agua en saturación de las cinco muestras graníticas. panallotriomorphic equigranular texture and shows no appreciable preferred orientation of minerals. Its major components are quartz, plagioclase, potassium feldspar, muscovite and biotite. Accessory minerals include apatite and zircon. "Baleante" granite is a medium-coarse grained leucogranite that is rich in muscovite and shows marked mineral orientation. It comprises mainly quartz, plagioclase, potassium feldspar, muscovite and biotite, with apatite as an accessory mineral. "Axeitos" granite is a mediumcoarse grained post-Hercynian granite that is pink in colour and shows slight mineral orientation.

Fluorescence microscopy of thin sections of the granites showed the degree and type of fissuration affecting them. Sound "Roan" (RS) presents mainly intragranular fissuration of plagioclase and intergranular fissuration of quartz, while sound "Baleante" (BS) shows intragranular fissuration of plagioclase and biotite, and inter-and transgranular fissuration of feldspar and quartz. The samples showing incipient weathering (RW and $B W$ ) show slightly more intense fissuration than the corresponding sound samples. "Axeitos" (AX) shows the highest density of transgranular fissures, together with some intergranular fissuration of quartz and potassium feldspar crystals.

The results of semiquantitative analysis of the granites by $X$-ray diffractometry are summarized in Table 1. As well as the essential granitic minerals listed above, traces of kaolinite were detected in both sound and weathered samples of all the granites, and traces of vermiculite were detected in the RS, RW and AX granites.

Table 2 lists mean values of the open porosity $(O P)$, real $(R D)$ and bulk density (BD) and water saturation (WS) of the granites. The samples showing incipient weathering had much greater open porosities than the sound samples, which accords with the differences in

\section{TABLA 1 (TABLE 1)}

Resultados semicuantitativos de la difracción de rayos $X$ de los granitos estudiados (Semiquantitative analysis of the granites by $X$-ray diffractometry)

\begin{tabular}{||l|c|c|c|c|c||}
\hline & $\mathbf{Q}$ & $\mathbf{F}$ & $\mathbf{M}$ & $\mathbf{K}$ & $\mathbf{V}$ \\
\hline RS & +++ & +++ & +++ & $\operatorname{tr}$ & $\mathrm{tr}$ \\
RA (RW) & +++ & +++ & ++ & $\operatorname{tr}$ & $\operatorname{tr}$ \\
BS & +++ & +++ & +++ & $\operatorname{tr}$ & - \\
BA (BW) & +++ & +++ & ++ & $\operatorname{tr}$ & - \\
AX & +++ & +++ & +++ & $\operatorname{tr}$ & $\operatorname{tr}$ \\
\hline
\end{tabular}

Q: Cuarzo; F: Feldespatos; M: Micas ; K: Caolinita; V: Vermiculita (Q: Quartz; F: Feldspars; M: Mica; K: Kaolinite; V: Vermiculite) $+++: 50-30 \% ;++: 10-30 \% ;+: 3-10 \%$; tr: $>3 \%$. 
Porosidad accesible (PA), densidad real (DR), densidad aparente (DA) y contenido de agua en saturación (Ws, \% en peso) de los granitos estudiados

(Mean bulk density (BD), real density (RD), open porosity (OP) and water saturation (WS) of the granites)

\begin{tabular}{||l|c|c|c|c|}
\hline & $\begin{array}{c}\text { DA (BD) } \\
\left(\mathbf{k g} / \mathbf{m}^{\mathbf{3}}\right)\end{array}$ & $\begin{array}{c}\text { DR (RD) } \\
\left(\mathbf{k g} / \mathbf{m}^{\mathbf{3}}\right)\end{array}$ & $\begin{array}{c}\text { PA (OP) } \\
(\%)\end{array}$ & $\begin{array}{c}\text { WS } \\
(\%)\end{array}$ \\
\hline RS & 2.607 & 2.662 & 2,07 & 0,79 \\
RA (RW) & 2.513 & 2.660 & 5,53 & 2,20 \\
BS & 2.562 & 2.637 & 2,84 & 1,11 \\
BA (BW) & 2.540 & 2.652 & 4,25 & 1,68 \\
AX & 2.565 & 2.619 & 2,06 & 0,80 \\
\hline
\end{tabular}

TABLA 3 (TABLE 3)

Cantidad de producto absorbido, materia seca tras la polimeración y consumo de ambos hidrofugantes. SL: Siliker, TS: Tegosivin

(Uptake of the water repellents: amount of water repellent absorbed, and the amount of dry polymer remaining in the rock 30 days after curing)

\begin{tabular}{||l|c|c|c|c|c|c|c|c||}
\hline & \multicolumn{9}{|c|}{ Consumo (Water repellent absorbed) } & \multicolumn{2}{c|}{$\begin{array}{c}\text { Materia seca } \\
\text { (Dry polymer } \\
\text { remaining) }\end{array}$} \\
\hline & \multicolumn{9}{|c|}{$(\%)(\%(\mathrm{~W} / \mathrm{W}))$} & \multicolumn{2}{|c|}{$\left(\mathrm{gr} / \mathrm{m}^{2}\right)$} & \multicolumn{2}{|c|}{$\left(1 / \mathrm{m}^{2}\right)$} & \multicolumn{2}{c|}{$\left(\mathrm{gr} / \mathrm{m}^{2}\right)$} \\
\hline & $\mathrm{SL}$ & $\mathrm{TS}$ & $\mathrm{SL}$ & $\mathrm{TS}$ & $\mathrm{SL}$ & $\mathrm{TS}$ & $\mathrm{SL}$ & $\mathrm{TS}$ \\
RS & 0,07 & 0,05 & 80 & 87 & 0,07 & 0,07 & 3,2 & 20 \\
RA (RW) & 0,16 & 0,16 & 184 & 200 & 0,16 & 0,17 & 7,2 & 28 \\
BS & 0,08 & 0,08 & 93 & 94 & 0,08 & 0,08 & 2,4 & 19 \\
BA (BW) & 0,13 & 0,12 & 168 & 147 & 0,15 & 0,13 & 88 & 63 \\
AX & 0,50 & 0,08 & 73 & 92 & 0,06 & 0,08 & 0,1 & 88 \\
\hline
\end{tabular}

Las muestras en un estado inicial de alteración poseen una elevada porosidad en comparación con las sanas, 10 que corrobora lo observado al microscopio óptico de fluorescencia. Esto indica que las diferencias entre ambas muestras son esencialmente de tipo físico, dada la similitud mineralógica.

\section{Consumo de los hidrofugantes}

En la tabla 3 se presentan los valores del consumo de hidrofugantes para cada granito, así como la cantidad de materia seca tras la polimeración. En general, todos los granitos absorben una cantidad similar de ambos productos, pero tras la polimeración, Tegosivin se encuentra en mayor cantidad que Siliker como materia seca en todas las muestras. Se observa que los valores del consumo son similares para ambos productos $y$ mayores en las muestras más porosas (RA y BA). Sin embargo, mediante este método de aplicación no se satisfacen los valores recomendados por el fabricante $\left(0.1-21 / \mathrm{m}^{2}\right)$, excepto para los granitos más porosos. their degrees of fissuration shown by fluorescence microscopy. This observation, together with the fact that the sound and weathered samples had similar mineralogy, suggests that the differences between RS and $\boldsymbol{R W}$ and $\mathrm{BS}$ and $\mathrm{BW}$ were mainly physical in nature.

\section{Uptake of the water repellents}

Table 3 lists various measures of the uptake of the water repellents by each granite, together with the amount of dry polymer remaining in the rock after curing. Generally, a given granite absorbed similar amounts of the two water repellents, but more

"Tegosivin" than "Siliker" remained in the rock after curing. Uptake was greatest for the most porous granites, $\boldsymbol{R W}$ and $\boldsymbol{B W}$.Indeed, with the exception of these granites, the method of application used did not afford uptakes as high as those recommended by the manufacturers $\left(0.1-2 \mathrm{l} / \mathrm{m}^{2}\right)$. 


\section{Profundidad de penetración}

A través de la observación de la diferencia de color producida por el mojado con agua de cortes realizados perpendicularmente a las superficies tratadas, se ha comprobado que la profundidad de penetración no supera los $2 \mathrm{~mm}$ de profundidad. Esto ocurre en todos los granitos y en ambos tratamientos.

Para medir de una manera más exacta esta profundidad, se han comparado las cinéticas capilares de las probetas antes y después de ser tratadas. Así, los valores obtenidos (Tabla 4) mediante este método, concuerdan con las observaciones realizadas a partir del cambio de color por el mojado de un corte superficial ( Tabla 3). Revelan una escasísima profundidad de penetración, la cual no parece estar determinada por la existencia de una mayor cantidad de materia seca del producto hidrofugante en la piedra.

\section{Modificaciones en el color}

Tras el tratamiento con ambos hidrofugantes, no se aprecian a simple vista cambios de color en ningún granito. Sin embargo, por colorimetría se detectaron pequeñas diferencias en los valores de las coordenadas $L^{*}, a^{*}$ y b* antes y después de ser tratadas (Figura 1) y el análisis de varianza (Tabla 5) señala la existencia, en algunos casos, de diferencias significativas entre los valores antes y después de los tratamientos.

En AX, la variaciones en las coordenadas $L^{*}$ y a* no son significativas después de tratarlo con Tegosivin y con Siliker. Sin embargo, las variaciones en la coordenada b* sí son significativas después de tratado con ambos productos; estos valores aumentan con los tratamientos, lo que indica un ligero amarilleamiento de la superficie.

Todas las coordenadas del color, excepto $L^{*}$ en las muestras tratadas con Siliker, fueron afectadas significativamente por la heterogeneidad de la roca (es decir, por el factor probeta) en el caso del granito de Axeitos. Sin embargo, la interacción del tratamiento

\section{Depth of penetration}

The cut-and-wet method indicated the depth of penetration of the water repellents to be less than $2 \mathrm{~mm}$ in all the granites.

Similarly low mean depths of penetration were estimated for the five granites from their kinetics of capillary absorption of test samples before and after treatments (Table 4). These values do not appear to correlate with uptake of the water repellent by the granite, or with the amount of dry polymer remaining in the rock after curing (see Table 3).

\section{Effects on surface colour}

Neither of the water repellents induced changes in the surface colour that were appreciable with the naked eye. However, small differences between the colour coordinates $L^{*}, a^{*}$ and $b^{*}$ before and after waterrepellent treatment were detected by colorimetry (Figure 1), and in some cases ANOVA revealed these differences to be statistically significant (Table 5).

For the AX granite, neither the lightness $L^{*}$ nor the saturation $a^{*}$ of the surface colour were significantly affected by application of "Tegosivin" or "Siliker". However, both treatments significantly altered the surface hue, inducing increases in $b^{*}$ indicative of yellowing.

All the colour co-ordinates except $L^{*}$ for the test samples treated with "Siliker" were significantly affected by the heterogeneity of the $\mathbf{A X}$ granite (i.e. by the random effect factor, "test sample"). However, the interaction "water repellent treatment" by "test

TABLA 4 (TABLE 4)

Profundidad de penetración estimada para los dos productos hidrofugantes, expresada en $\mathrm{mm}$ (Estimated depth of penetration (in $\mathrm{mm}$ ) of the water repellents into the five granites)

\begin{tabular}{||l|c|c|}
\hline & SILIKER & TEGOSIVIN \\
\hline RS & 1,2 & 0,96 \\
RA (RW) & 1,47 & 1,44 \\
BS & 1,15 & 1,77 \\
BA (BW) & 0,90 & 0,90 \\
AX & 1,33 & 0,99 \\
\hline
\end{tabular}



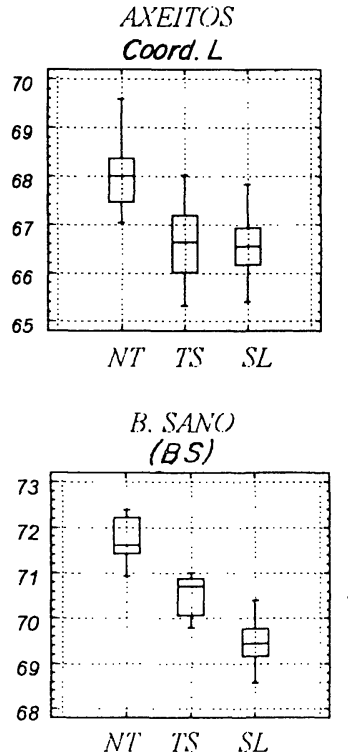

B. ALTERAL)

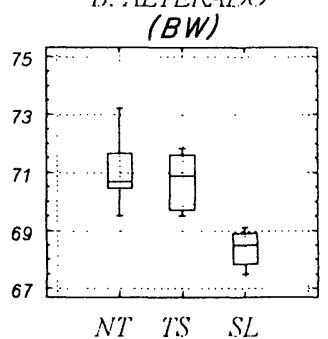

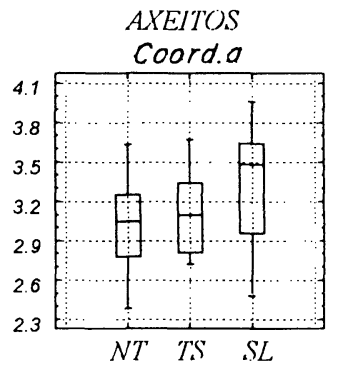

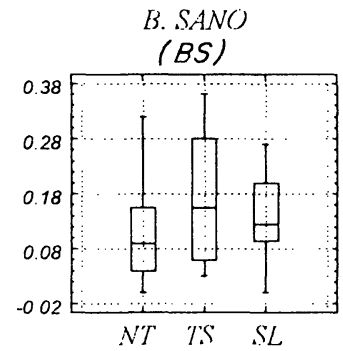

B. ALTKRAL)(

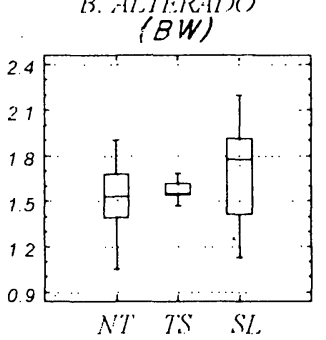

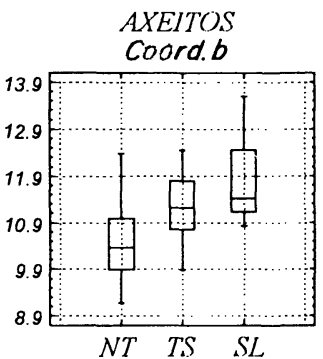

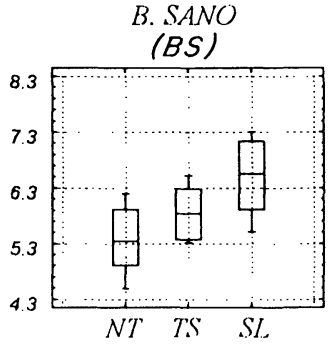

B. AL.TLRAL()

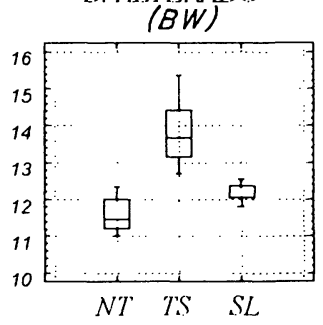

Fig. 1.- Gráfions de distribuciones de los valores de las coordenadas $L^{*}, a^{*}$ y $b^{*}$ antes de tratar (NT) y después de los tratamientos con Siliker (SL) y Tegosivin (TS).

Fig. 1.-Box-and-whisker plots showing the distributions of the colourcoordinates $L^{*}, a^{*}$ and $b^{*}$ forthe untreated (NT), Silikertreated and Tegosivintreated (TS).

hidrofugante con el factor probeta no tuvo efecto significativo $(p \geq 0,016)$ sobre las coordenadas del color, ni siquiera sobre $b^{*}$ que es la única que es afectada significativamente por los tratamientos y el factor probeta. Esto significa que el efecto del hidrofugante es real, independientemente de que exista una influencia de la heterogeneidad de la roca.

En BS se encuentran diferencias significativas tras el tratamiento con ambos hidrofugantes en los valores de la coordenada $L^{*}$, los cuales disminuyen indicando un oscurecimiento del color original. Al contrario que en esta coordenada donde el efecto probeta carece de significación, en las coordenadas $\mathrm{a}^{*} \mathrm{y} \mathrm{b}^{*}$ se encuentra que, si bien sobre ellas, el tratamiento carece de efecto, la heterogeneidad de la roca influye de forma significativa en su determinación.

En BA tratado con Tegosivin se ha realizado un análisis de varianza simple, debido a que se disponía únicamente de una probeta para este tratamiento. Este análisis indica diferencias significativas entre las probetas no tratadas y tratadas con este producto sample" had no significant effect ( $p \geq 0.016)$ on the colour coordinates, not even on $b^{*}$, which had been significantly affected by both treatment and test sample. This indicates that the water repellent affects $b^{*}$ regardless of the effect of the heterogeneity of the test sample.

For the BS granite, the water repellents had significant effects only on the value of $L^{*}$, which decreased, indicating darkening of the surface colour. By contrast, heterogeneity among the test samples had significant effects on $a^{*}$ and $b^{*}$, but not on $L^{*}$.

For the BW granite treated with "I'egosivin" an analysis of one-way variance was carried out owing to a unique test sample was available. This treatment had 
TABLA 5 (TABLE 5)

Significación del efecto de los factores tratamiento (tto), probeta (pb) y de la interacción entre ambos (tto*pb) en el análisis de varianza de los resultados de la determinación colorimétrica (valores para las coordenadas $L$, a y b), permeabilidad al vapor, ángulo de contacto y tiempo de absorción de microgotas de los granitos

(Results of analysis of variance to assess the significance of the effects of the factors "Water repellent treatment" (WR) and "test sample" (S), together with their first degree interaction (WR * S), on the granites' colour, permeability to water vapour, rock-water contact angle, and relative microdroplet absorption time)

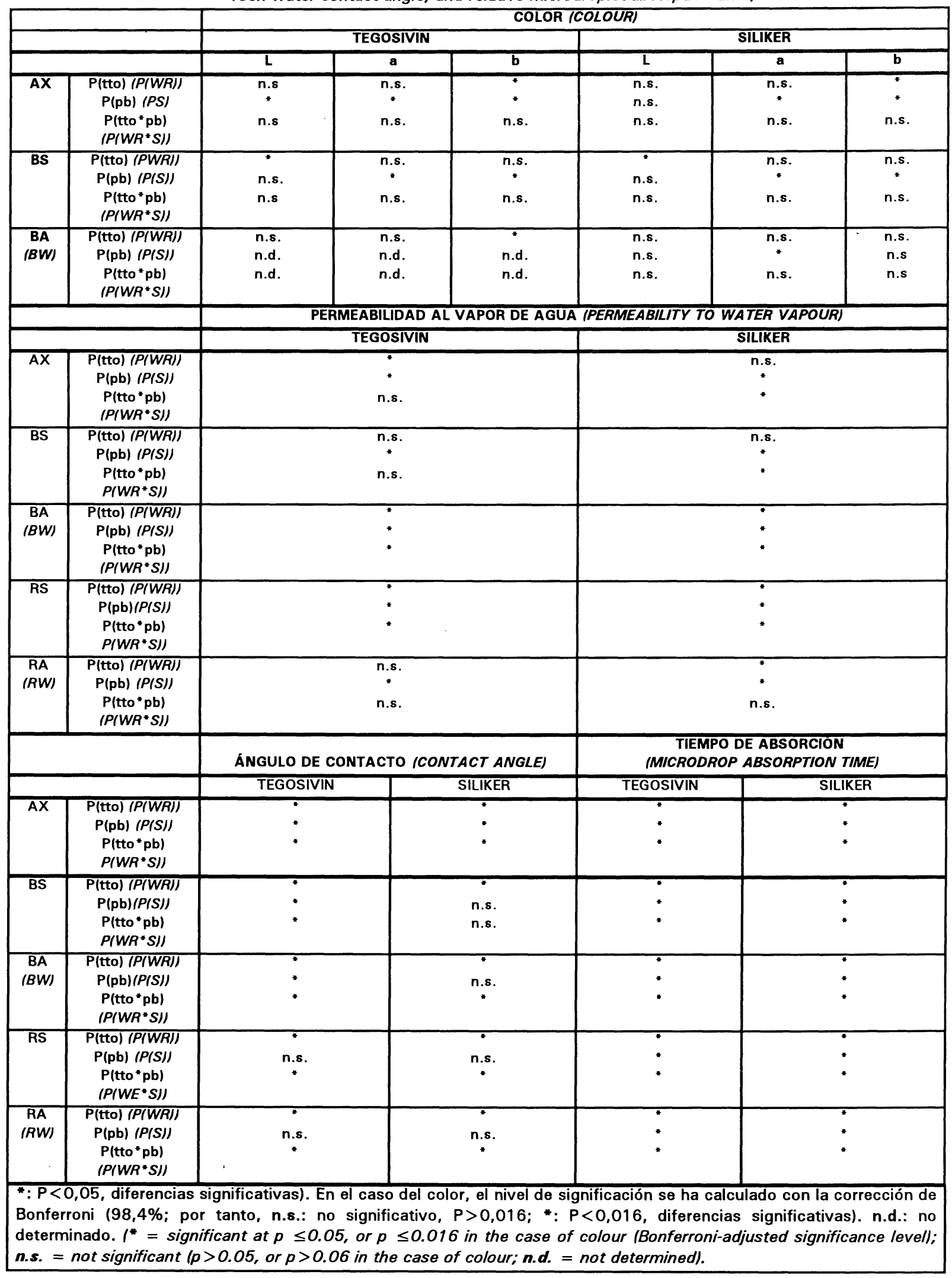


únicamente en los valores de la coordenada b*. Estos valores tienden a aumentar, lo que se interpreta como amarilleamiento de la tonalidad de la roca.

\section{Modificaciones en la permeabilidad al vapor}

En la tabla 6 se presentan los valores medios de los coeficientes de permeabilidad al vapor de cada granito antes y después de los tratamientos y en la figura 2, las distribuciones de los coeficientes de permeabilidad al vapor. En términos generales, se aprecia que los significant effects on $b^{*}$, which increased, indicating yellowing of the surface colour.

\section{Effects on permeability to water vapour}

Figure 2 shows the distributions of the coefficients of vapour permeability of the untreated and treated granites, and table 6 lists the mean values of these coefficients. Both water repellents generally caused the vapour permeability to decrease, except in the case of
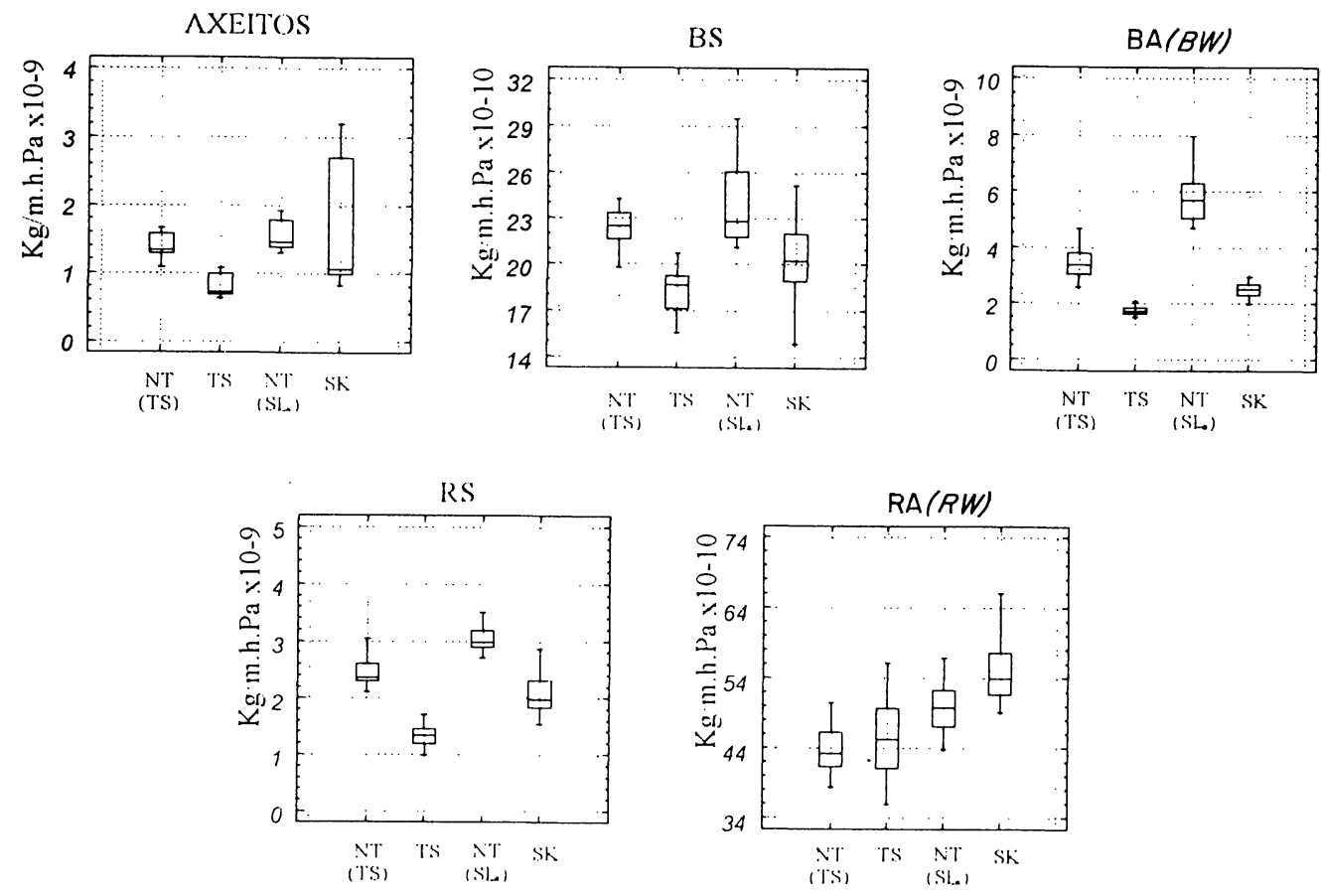

Fig. 2.- Gráficos de distribuciones de los valores de permeabilidad al vapor de los granitos antes de tratar (NT) y después de los tratamientos con Siliker (SL) y Tegosivin (TS).

Fig. 2.-Box-and-whisker plots showing the distributions of the coefficients of vapour permeability forthe untreated (NT), Siliker treated (SL) and Tegosivin treated (TS) granites.

\section{TABLA 6 (TABLE 6)}

Valores medios del coeficiente de permeabilidad al vapor de los granitos antes y después de tratarlos con los hidrofugantes. Valores expresados en $\mathrm{kg} / \mathrm{m} \cdot \mathrm{h} \cdot \mathrm{Pa}$

(Mean coefficients of vapour permeability $(\mathrm{kg} / \mathrm{m} \cdot \mathrm{h} \cdot \mathrm{Pa}$ ) of the tests samples before and after treatment with each water repellent)

\begin{tabular}{||l|c|c|c|c||}
\hline & \multicolumn{2}{|c|}{ SILIKER } & \multicolumn{2}{c||}{ TEGOSIVIN } \\
\hline & ANTES (BEFORE) & DESPUÉS (AFTER) & ANTES (BEFORE) & DESPUÉS (AFTER) \\
RS & $3.09 \cdot 10^{-9}$ & $2.08 \cdot 10^{-9}$ & $2.48 \cdot 10^{-9}$ & $1.66 \cdot 10^{-9}$ \\
RA (RW) & $4.90 \cdot 10^{-9}$ & $5.28 \cdot 10^{-9}$ & $4.29 \cdot 10^{-9}$ & $5.08 \cdot 10^{-9}$ \\
BS & $2.40 \cdot 10^{-9}$ & $2.03 \cdot 10^{-9}$ & $2.23 \cdot 10^{-9}$ & $1.83 \cdot 10^{-9}$ \\
BA (BW) & $5.77 \cdot 10^{-9}$ & $2.47 \cdot 10^{-9}$ & $3.43 \cdot 10^{-9}$ & $1.73 \cdot 10^{-9}$ \\
AX & $1.47 \cdot 10^{-9}$ & $1.62 \cdot 10^{-9}$ & $1.27 \cdot 10^{-9}$ & $1.69 \cdot 10^{-9}$ \\
\hline
\end{tabular}


tratamientos tienden a disminuir los coeficientes de permeabilidad al vapor de los granitos excepto en el caso de RA. Esta reducción es estadísticamente significativa $(p \leq 0,05)$ en los granitos RS y BA (Tabla 5). En ambos granitos se observa, además, un efecto significativo del factor probeta en la permeabilidad al vapor; por otra parte, el nivel de significación de la interacción entre ambos factores, menor de 0,05 , señala que las probetas se comportan de manera diferente frente a los tratamientos, es decir, que la variación observada no se debe únicamente al efecto de los tratamientos.

BS no ve modificada su permeabilidad tras ninguno de los dos tratamientos, sin embargo, se observa una influencia significativa del factor probeta en la determinación de esta propiedad.

En AX, sólo Tegosivin tiene un efecto significativo en su permeabilidad, reduciendo el valor original. El efecto del factor probeta sobre la medida de esta propiedad es estadísticamente significativo; sin embargo, el hecho de que la interacción no sea significativa indica que todas las muestras se comportan de igual forma frente al tratamiento con este hidrofugante, es decir, éste tiene un efecto real sobre la permeabilidad de la roca.

En las muestras tratadas con Siliker se obtiene un efecto significativo del factor probeta, así como de la interacción de ambos factores. Esto puede interpretarse como que el tratamiento, que no afecta significativamente al conjunto de datos, sí lo hace en alguna probeta en concreto.

En RA, únicamente el tratamiento con Siliker tiene un efecto significativo en la permeabilidad al vapor que, al contrario que en los otros granitos, aumenta su valor original. Se observa, al igual que en el tratamiento con Tegosivin, una significativa influencia del factor probeta. Sin embargo, la interacción no significativa en el caso de Siliker indica que todas las probetas se comportan de igual forma frente al tratamiento, teniendo entonces éste un efecto claro sobre la permeabilidad

\section{Medida de la eficacia de los hidrofugantes}

\section{Tiempo de absorción de microgotas}

En la figura 3a se representan las distribuciones de los valores de tiempo de absorción de microgotas de cada probeta para los cinco granitos antes de los tratamientos. Se observa que este parámetro está fuertemente influido por la porosidad de las rocas the $R W$ granite. These decreases were statistically significant ( $p \leq 0.05$ ) in the case of the RS and BW granites (Table 5). However, in both cases the heterogeneity of the test sample also had a significant effect on VP, and there was a significant first degree interaction between these two factors. Thus the observed decreases cannot be attributed to the water repellent alone.

Neither of the water repellents had significant effects on the VP of the BS granite, but the effect of the heterogeneity of the BS test samples on VP was significant.

Only "Tegosivin" had a statistically significant effect on the VP of the AX test samples. The effect of the heterogeneity of the test samples was also statistically significantly; however, there was no interaction, indicating that "Tegosivin" had produced a real decrease in the vapour permeability of all the test samples.

For the AX samples treated with "Siliker", the water repellent did not have a significant effect on $V P$, whereas "test sample" and the first degree interaction both did. This suggests that although the water repellent had no significant effect on the mean $V P$, it was causing significant changes in the VP of isolated test samples.

Only "Siliker" had a significant effect on the VP of the $\boldsymbol{R} \boldsymbol{W}$ test samples. In contrast to the effects of both "Tegosivin" and "Siliker" on the other granites, "Siliker" increased the VP of the RW granite. Again the heterogeneity of the test sample significantly affected VP, but there was no first-degree interaction.

\section{Determination of the efficacy of the water repellents}

\section{Microdroplet absorption time}

Figure 3 a shows the distributions of the relative microdroplet absorption times for each untreated test sample of the five granites. The microdroplet absorption time was shortest in the most porous granites, and 
graníticas: en los granitos más porosos (RA y BA) los valores del tiempo de absorción son más bajos que en los granitos menos porosos (RS, BS y AX).

En AX se observa que los valores son más elevados que los del resto de los granitos, incluso comparativamente a aquel de porosidad similar (RS). Por microscopía de fluorescencia se comprobó que el granito de $\mathbf{A X}$ tiene fisuras de tamaño mayor que el resto de los granitos, y fundamentalmente de tipo transgranular. Por otra parte, tiene un tamaño de grano medio-grueso, de forma que si las microgotas caen en minerales aislados, escasamente fisurados, son absorbidas en un tiempo mayor, al contrario de lo que ocurre en los otros granitos, donde la fisuración es de tipo inter e intragranular, afectando a cada grano en particular.

En la figura $3 b$ se muestran las distribuciones de los valores del tiempo de absorción de microgotas obtenidos para las mismas probetas después de los tratamientos y en la tabla 7 los valores medios para cada granito antes y después de los mismos.

Los resultados muestran claramente el efecto de los hidrofugantes, en la medida en que la capacidad de mojado de las superficies rocosas se reduce increased as the open porosity $(\mathrm{RW}<\mathrm{BW}<\boldsymbol{B S}<\boldsymbol{R S}$ $\boldsymbol{A X})$.

The AX granite absorbed microdroplets much slower than even the RS granite, which has comparable porosity. This slow absorption may be related to the $A X$ granite's medium-coarse texture and its predominantly transgranular fissuration: $a$ microdroplet falling on $\mathrm{AX}$ would be more likely to fall on a single mineral grain, but since the minerals of $A X$ show only slight intergranular fissuration and virtually no intragranular fissuration the microdroplet would be absorbed more slowly than on the other granites.

For the same test samples, figure $3 b$ shows the distributions of the relative microdroplet absorption times following application of the water repellents. The corresponding pre- and post-treatment mean values are listed in table 7.

The treated samples all had much longer microdroplet absorption times, due to a decrease in the wetting
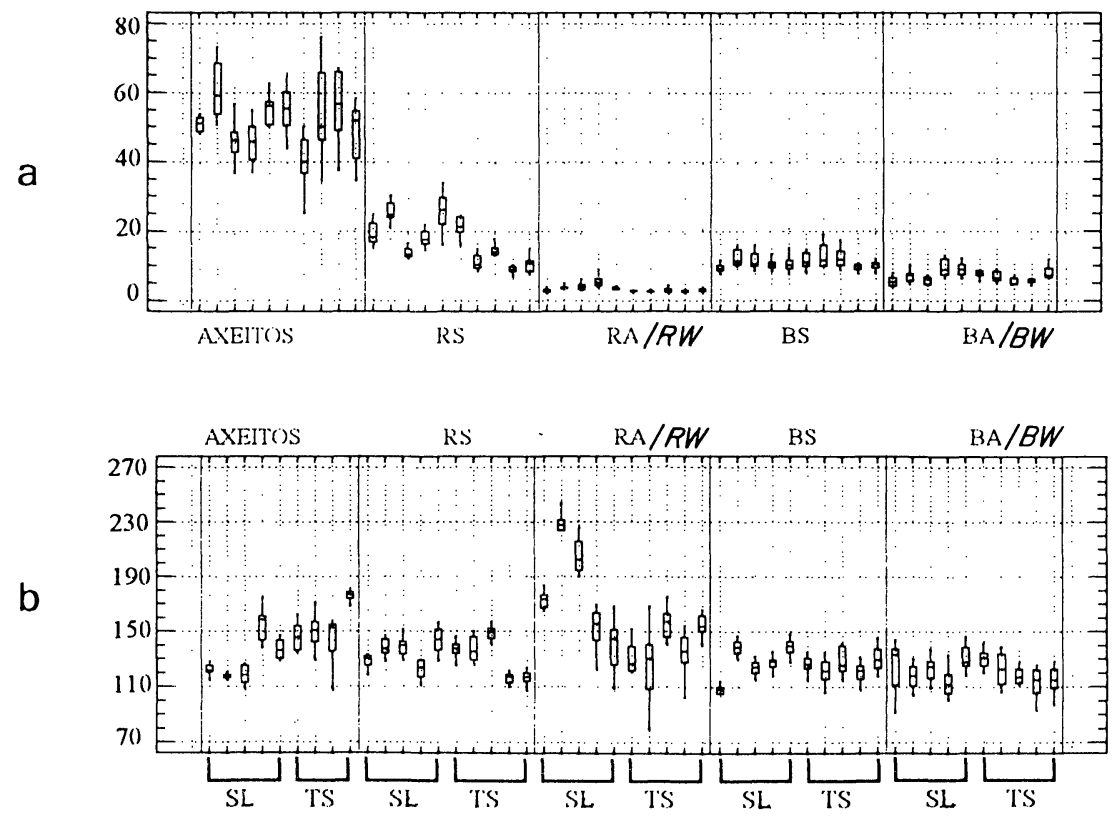

Fig 3.- Valores del tiempo de absorción de microgotas, representados en cajas de distribución, para cada probeta de los cinco granitos antes de los tratamientos con Siliker (SL) y Tegosivin (TS) (a) y después de los mismos (b).

Fig. 3.- Box-and-whiskerplots showing the distributions of the relative microdroplet absorption times of each test sample a) before treatment; and b) after treatment with Siliker (SL) or Tegosivin (TS). 
Valores medios del tiempo de absorción de microgotas $(\%)$ antes y después de los tratamientos con Siliker y Tegosivin

(Mean relative microdroplet absorption times $1 \%$ ) of each granite before and after treatment with Siliker or Tegosivin)

\begin{tabular}{|l|c|c|c|}
\hline & $\begin{array}{c}\text { SIN TRATAR } \\
\text { (UNTREATED) }\end{array}$ & SILKER & TEGOSIVIN \\
\hline AX & 51 & 129 & 153 \\
RS & 16 & 134 & 130 \\
RA (RW) & 3 & 180 & 140 \\
BS & 11 & 126 & 125 \\
BA (BW) & 7 & 121 & 118 \\
\hline
\end{tabular}

significativamente, hecho que se ve apoyado por las diferencias significativas obtenidas en el análisis de varianza (Tabla 5).

Ambos productos, Tegosivin y Siliker, actúan cuantitativamente de modo similar en todos los granitos. Sin embargo, en la medida de este parámetro, se obtiene, sobre todo después de los tratamientos, una elevada variabilidad entre los valores obtenicos para cada probeta. Esta variabilidad se constata en los resultados del análisis de varianza (Tabla 5) que indican un efecto significativo del factor probeta en esta determinación. Este efecto puede estar determinado por las características texturales de este tipo de rocas, como la granulometría y, en concreto, el tipo de fisuración predominante; así, el tiempo de absorción de una microgota será muy diferente dependiendo sobre qué mineral caiga.

Asimismo, se obtiene que el efecto de la interacción de ambos factores, tratamiento y probeta, es significativo, lo que indica que no sólo el tratamiento sino también las caracteristicas mencionadas son responsables de estas variaciones.

\section{Ángulo de contacto roca-agua}

En la figura $4 a$ y $4 b$, se presentan las distribuciones de los valores el ángulo de contacto obtenidos para cada probeta de los cinco granitos antes y después de los tratamientos. Los valores medios de este parámetro se muestran en la tabla 8.

En todos los casos, el producto Siliker presenta una mayor eficacia en la hidrofugación que Tegosivin; (Figura 4, Tabla 8); esto llama la atención en el caso de AX donde Siliker mostró una menor eficacia que Tegosivin en el aumento del tiempo de absorción de microgotas. capacity of the granite surface. In all cases the factor "water repellent" had had a significant effect (Table 5).

"Tegosivin" and "Siliker" induced quantitatively similar increases in the microdroplet absorption time of the granites. Nonetheless, there was considerable variation in relative microdroplet absorption time among the different test samples, especially among the treated samples. Indeed, in all cases ANOVA (Tabla 5) showed the factor "test sample" and also the firstdegree WR by $S$ interaction to have had a significant effect on the value of this parameter.

These effects may be attributable to variations in the mineralogy, particle size and/or fissuration of the surface, which can determine both uptake of the water repellent and absorption of the microdroplet.

\section{Rock-water contact angle}

The distributions of the rock-water contact angles for each untreated and treated test sample of the five granites are shown in Figures $4 a$ and $4 b$, respectively. The corresponding mean values of this parameter are listed in table 8.

All the "Siliker"-treated granite sampies had greater water-repellency than the "Tegosivin"-treated samples (Figure 4, Table 8), even in the case of the AX granite, 


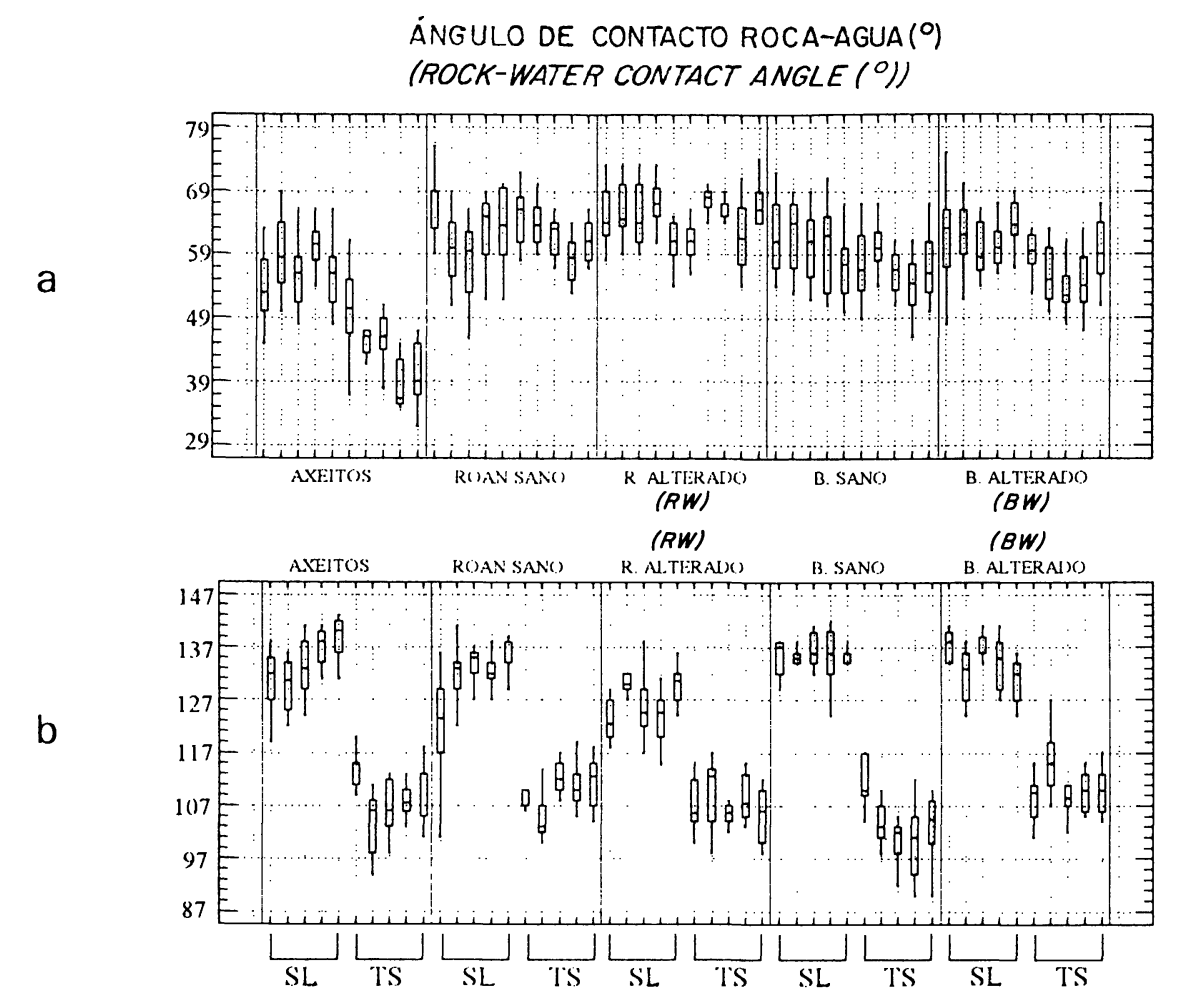

Fig. 4.- Valores del ángulo de contacto roca-agua ( $\%$, representados en cajas de distribución, para cada probeta de los cinco granitos, antes (a) y después (b) de los tratamientos con Siliker (SL) y Tegosivin (TS).

Fig. 4.- Box-and-whisker plots showing the distributions of the rock water contact angle ( ) of each test sample a) before treatment; and b) after treatment with Siliker (SL) or Tegosivin (TS).

TABLA 8 (TABLE 8)

Valores medios del ángulo de contacto roca-agua $\left({ }^{\circ}\right)$ antes y después de los tratamientos con Siliker y Tegosivin

(Mean rock-water contact angles $(\%)$ of each granite before and after treatment with Siliker or Tegosivin)

\begin{tabular}{||l|c|c|c|}
\hline & $\begin{array}{c}\text { SIN TRATAR } \\
\text { (UNTREATED) }\end{array}$ & TEGOSIVIN & SILIKER \\
\hline AX & 50 & 108 & 133 \\
RS & 62 & 109 & 131 \\
RA (RW) & 64 & 107 & 126 \\
BS & 58 & 103 & 135 \\
BA (BW) & 59 & 110 & 134 \\
\hline
\end{tabular}

El análisis de varianza (Tabla 5) muestra que a pesar de la evidente diferencia entre los valores de las cinco probetas tratadas con Siliker y los valores de las cinco tratadas con Tegosivin, existe un efecto muy significativo del factor probeta en AX, BS, BA y RS tratados con Tegosivin y en AX tratado con Siliker. Asimismo, el análisis indica que frente a cada tratamiento, las probetas se comportan de distinta forma, lo cual indica que las variaciones observadas en este parámetro no sólo son debidas al efecto de los tratamientos. for which microdroplet absorption had been slower for the "Tegosivin"-treated samples than for the "Siliker"treated samples. However, for the $A X, B S, B W$ and $R S$ samples treated with "Tegosivin" and the Ax samples treated with "Siliker" a statistically significant part of the increase in rock-water contact angle was due to the factor "test sample" (Table 5). 


\section{CONCLUSIONES}

Las consideraciones que se pueden establecer con respecto a los dos productos ensayados son las siguientes: en primer lugar, a pesar de ser químicamente similares, difieren significativamente en la cantidad de materia seca que finalmente permanece en la piedra tras la polimeración, siendo mayor en el caso de Tegosivin. Es posible, que en el caso de Siliker, la materia activa de la mezcla aplicada sea arrastrada hacia la superficie durante la evaporación del disolvente, polimerizando en superficie, o que únicamente penetre el disolvente en la piedra junto con una escasa cantidad de materia activa.

La escasa penetración se produce en todos los granitos sin excepción, ya sean alterados o sanos, y parece ser independiente de la mineralogía o tamaño de grano de la roca. Sin embargo, es posible que influya el hecho de que las rocas escogidas poseen una porosidad demasiado baja como para que a través del método de aplicación (útil para establecer comparaciones en ensayos de laboratorio), se consiga una buena absorción y profundidad de penetración.

Ni la escasa penetración ni el bajo consumo inciden negativamente en la eficacia de los productos, ya que ambos reducen significativamente la tendencia al mojado de las superficies. Los dos parámetros utilizados para valorar esta eficacia, el tiempo de absorción de microgotas y el ángulo de contacto rocaagua, resultan ser muy útiles en la valoración de la eficacia de tratamientos hidrofugantes pero cuando se trata de estudios sobre rocas graníticas, los resultados de este trabajo indican la necesidad de determinar dichos parámetros en un número mayor de muestras, y con un mayor número de determinaciones por muestra, dado el fuerte efecto que sobre estos parámetros, sobre todo en el tiempo de absorción de microgotas, presentan ciertas características de las rocas graníticas, fundamentalmente su textura, mineralogía y tipo de fisuración.

Los tratamientos no provocan cambios significativos del color original de las rocas, aunque se han detectado variaciones de las coordenadas colorimétricas, lo que indica que el método utilizado es muy sensible a pequeños cambios de color, lo cual lo hace quizás muy eficaz, no sólo a la hora de valorar los efectos de los tratamientos sobre el aspecto de las rocas sino también a la hora de valorar la durabilidad del producto.

La modificación en la permeabilidad al vapor de las rocas por los tratamientos, muy significativa en algunos casos, parece ser independientemente de la cantidad de producto absorbido o del porcentaje de materia seca tras el curado. Teniendo en cuenta que, en

\section{CONCWUSTONS}

In the light of the above results, it would appear that although "Tegosivin" and "Siliker" are chemically similar, they differ in that more "Tegosivin" than "Siliker" remains in the treated rock as dry polymer after curing. A possible explanation for this difference might be that, during drying of "Siliker", evaporation of the organic solvent forced the water repellent out of pores and onto the rock surface. Alternatively, only a small amount of active material may have penetrated into the rock along with the solvent.

The poor penetration of the water repellents into the granites does not seem to depend on characteristics such as the mineralogy, texture or degree of weathering of the granite. Rather, it was probably due to the low porosities of the granites examined and to absorption of insufficient active material by the method of application used in this laboratory study.

The low uptake and poor penetration of the two water repellents did not appear to affect their capacity to reduce surface wetting. The parameters relative microdroplet absorption time and rock-water contact angle appear to be suitable for evaluation of the efficacy of water repellents applied to granitic rocks. However, a large number of replications must be performed in order to eliminate the effects on these parameters (especially microdroplet absorption time) of variations in the texture and mineralogy of the test sample and in the type and degree of fissuration affecting it.

Neither of the water repellents appreciably alter the original colour of the rock. Nonetheless, colorimetric analysis of the treated surface showed that the treatments do induce small but significant alterations in the colour co-ordinates $L^{*}, a^{*}$ and $b^{*}$. These results confirm the high sensitivity of the colorimetric method used, and suggest that it may be useful for evaluation of the durability of water-repellent treatments.

Both water repellents reduce the permeability to water vapour of the granite samples, though in this work these reductions were not always statistically significant. Although these reductions did not appear to be related to uptake of the water repellent or to the 
este trabajo, la reducción de la permeabilidad al vapor se produce con una cantidad muy baja de materia seca, se hace obligado que en futuros trabajos, la valoración de la influencia de los tratamientos en esta propiedad se realice tras una aplicación de los productos más cercana a la aconsejada por el fabricante. Esta propiedad se encuentra fuertemente influida por la heterogeneidad de las rocas graníticas, por lo que también es recomendable incrementar el número de probetas en la determinación de este parámetro en estudios sobre tratamientos en este tipo de rocas.

\section{AGRADECIMIENTOS}

Este trabajo fue financiado por la D.G.C.I.C.Y.T. dentro del Proyecto SEC94-0381. Gracias tambien a José Calvo García y a Elvio Ramos por su ayuda en el trabajo experimental y a José Sánchez, por su ayuda con la estadística. amount of dry polymer remaining in the rock after curing, further work must be carried out to evaluate these effects more fully, at penetrations greater than those achieved here and thus closer to the values recommended by the manufacturers. In such work, a larger number of test samples should be used, so as to eliminate the strong effects that sample heterogeneity has on this parameter.

\section{ACKNOWLEDGEMENTS}

This work was financed by the Spanish DGCICYT as part of Research Project SEC94-0381. The authors thank José Calvo Garcia and Elvio Ramos for their help with the experimental work, and José Sánchez for help with the statistical analysis.

\section{BIBLIOGRAFÍA}

(1) REUNION INTERNATIONALE DES LABORATOIRES D'ESSAIS ET DE RECHERCHE SUR LES MATERIAUX ET LES CONSTRUCTIONS (R.I.L.E.M.). COMISSION 25 PEM. PROTECTION ET EROSION DES MONUMENTS: (1980).Recommandations provisoires. Essais recommandés pour mesurer l'alteration des pierres et évaluer l'efficacité des méthodes de traitement. Materiaux et constructions. Vol 13. $\mathbf{n}^{\circ}$ 75. Test $\mathbf{n}^{\circ}$. I.2.: Bulk densities and real densities. Test $\mathbf{n}^{\circ}$. I.1.: Porosity accesible to water.

(2) ISTITUTO CENTRALE DEL RESTAURO-COMMISSIONE NORMAL (I.C.R.-C.N.R.). ALTERAZIONI DEI MATERIALI LAPIDEI E TRATTAMENTI CONSERVATIVI. PROPOSTE PER L'UNIFICAZIONE DEI METODI SPERIMENTALI DI STUDIO E DI CONTROLO: (1985).- Permeabilità al vapor d'acqua. Doc. Normal 21/85.

(3) FERREIRA, A.P.: (1993).- Conservaçao de pedras graníticas. Estudo da acçao de hidrófugos. Dissertaçao para a obtençao do grau de mestre en construç̧ao. Itto. Superior Técnico, Universidade Tecnica de Lisboa. 185 pp.

(4) DELGADO, J.; COSTA, D.; FERREIRA, A.P.: (1994).- The use of water absorption characteristics for the study of stone treatments. Proc. Workshop Degradation and Conservation of Granitic Rocks in Monuments. Santiago de Compostela, noviembre, 1994. 